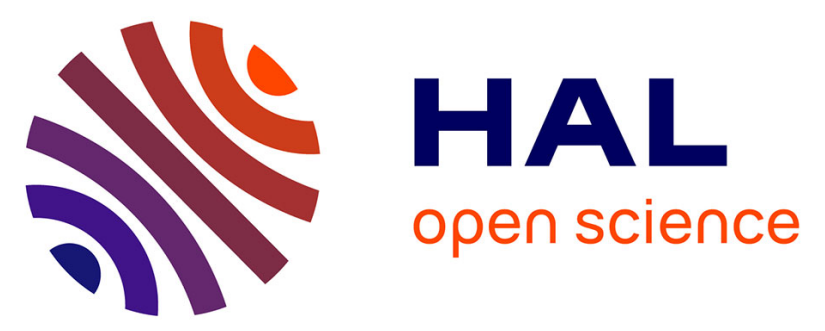

\title{
Role of heat-flux density and mechanical loading on the microscopic heat-checking of high temperature tool steels under thermal fatigue experiments
}

\author{
Sabine Le Roux, Farid Medjedoub, Gilles Dour, Farhad Rezai-Aria
}

\section{- To cite this version:}

Sabine Le Roux, Farid Medjedoub, Gilles Dour, Farhad Rezai-Aria. Role of heat-flux density and mechanical loading on the microscopic heat-checking of high temperature tool steels under thermal fatigue experiments. International Journal of Fatigue, 2013, 51, pp.15-25. 10.1016/j.ijfatigue.2013.02.004 . hal-01666697

\section{HAL Id: hal-01666697 https://hal.science/hal-01666697}

Submitted on 18 Mar 2019

HAL is a multi-disciplinary open access archive for the deposit and dissemination of scientific research documents, whether they are published or not. The documents may come from teaching and research institutions in France or abroad, or from public or private research centers.
L'archive ouverte pluridisciplinaire HAL, est destinée au dépôt et à la diffusion de documents scientifiques de niveau recherche, publiés ou non, émanant des établissements d'enseignement et de recherche français ou étrangers, des laboratoires publics ou privés. 


\title{
Role of heat-flux density and mechanical loading on the microscopic heat-checking of high temperature tool steels under thermal fatigue experiments
}

\author{
S. Le Roux, F. Medjedoub ${ }^{1}$, G. Dour ${ }^{2}$, F. Rézaï-Aria* \\ Université de Toulouse, Mines Albi, INSA, UPS, ISAE, ICA (Institut Clément Ader), Campus Jarlard F-81013 Albi Cedex 09, France
}

\begin{abstract}
A B S T R A C T
Thermal fatigue of a hot work tool steel (X38CrMoV5) is investigated under various test conditions. A microscopic interconnected heat-checking pattern forms on the oxidized surface of the specimen. The evolution of the crack density and morphology is characterized by Scanning Electron Microscopy (SEM) and image analysis. The effects of the initial hardness, the maximum temperature and the heating period of the thermal cycle are reported. It is shown that the saturated heat-checking density is independent of the maximum temperature of the thermal cycle, but is dependent on the heating rate. No significant effect of the initial hardness is observed. In the saturated regime, a linear relationship is established between the heat-checking density and the maximum heat-flux density applied to the specimen. The saturated crack density is explained by the difference between the thermo-mechanical strains of the oxide layer and the steel. A damage criterion, independent of the initial hardness of the steel, is proposed to describe the microscopic heat-checking life.
\end{abstract}

Keywords:

Thermal fatigue

Crack network

Image analysis

Heat-checking life

Hot work tool steel

\section{Introduction}

Thermal fatigue (TF) is a major life-limiting factor of several key industrial components, like hot-forming tool (rolling mill rolls [1,2], moulds for die casting or forging [3-8]), engine cylinder heads and blocks in automotive industry [9], gas-turbine blades in aircraft engines [10] and pressurized water reactors in nuclear industry $[11,12]$. These components, as with the laboratory samples, experience the variation of temperature with time, during start-up (heating) and shutdown (cooling) operations $[2,9]$ or thermal fluctuations in service $[3-8,10]$. The repetition of these thermal fluctuations induces transient thermal gradients, which result in thermal strains and subsequent stresses by self-constraining of component or sample. It should be remembered that the surface of the tools is also subjected to additional efforts required to form parts. The cyclic thermo-mechanical solicitations are further coupled with reactive environments (such as oxidation in hot forging and/or corrosion in die-casting), which can lead to a dissolution ("wash-out") of the dies $[3,13]$.

In high temperature forming processes (e.g. High-pressure Die Casting, hot-stamping or forging), the heat exchange between the molten alloy (or hot part) and the die increases the temperature

\footnotetext{
* Corresponding author. Tel.: +33 563493082; fax: +33 563493099.

E-mail address: rezai@mines-albi.fr (F. Rézaï-Aria).

1 Present address: Airbus France, Site de Saint Martin du Touch, 316 Route de Bayonne, 31060 Toulouse Cedex 9, France.

2 Present address: NOPSEMA, Level 08 Alluvion Bld., 58 Mounts Bay Road, Perth, 6000 WA, Australia.
}

of the surface. However, the heat-flux density and thus the maximum temperature $\left(T_{\max }\right)$ may vary from one region to another, depending on tool design and dimensions (e.g. small or large), and/or processing conditions [6,8]. Therefore, the resulting thermo-mechanical stress-strain hysteresis loops differ locally. One can assume that each sector of a tool is a TF specimen experiencing specific test conditions (applied temperatures $T_{\min }$ and $T_{\max }$, transient thermal gradient, heating and cooling rates, etc.). According to the amplitude of the thermo-mechanical solicitation, thermoplastic or thermo-visco-plastic yielding can occur and lead cracks to initiate and propagate under non-isothermal fatigue conditions. Near geometrical singularities constituting stress raisers (e.g. corners, holes, etc.), a uniaxial thermo-mechanical fatigue state prevails and the amplitude of the solicitation is in general high enough to initiate and propagate very early the first cracks $[4,6]$. On planar surfaces, a network of interconnected cracks, commonly named "heat-checking", is initiated and propagated under multiaxial (or at least bi-axial) thermo-mechanical loading [3-6,14]. As the tool is facing cyclic oxidation and/or corrosion reactions, a multi-layered material (oxide or others scales) can be formed. The diffusion of chemical elements (like oxygen, chromium, and iron) changes the composition of the surface and may alter its mechanical properties and strength $[7,13]$. The cracking of this "multi-layered" material results from mechanical loading induced by the mismatch of thermal expansion between an oxide layer (with elastic behaviour) and the substrate steel (with an elastovisco-plastic behaviour) [3,5,6,8]. During hot forming, the "free" thermal expansion of the die surface is (self-)constrained by the 


\begin{tabular}{|c|c|c|c|}
\hline \multicolumn{4}{|c|}{ Nomenclature } \\
\hline A & area of the heat-checking cells & $W_{c}$ & critical input energy \\
\hline$c$ & Manson-Coffin exponent & $z z$ & longitudinal axis of the specimen \\
\hline $\mathrm{cr}$ & mean cooling rate of the thermal cycle & $\alpha$ & coefficient of thermal expansion \\
\hline$c t$ & cooling time of the thermal cycle & $\varepsilon_{p}$ & plastic strain \\
\hline C & compactness factor of the heat-checking cells & $\varepsilon_{t}$ & total strain \\
\hline$d \varepsilon / d t$ & creep strain-rate & $\rho_{h c}$ & heat-checking density \\
\hline$h r$ & mean heating rate of the thermal cycle & $\rho_{\text {sat }}$ & saturated heat-checking density \\
\hline$h t$ & heating time of the thermal cycle & $\theta$ & orientation of micro-crack branches \\
\hline$L_{\text {sat }}$ & saturation crack spacing & $\theta \theta$ & circumferential axis of the specimen \\
\hline$m$ & strain rate exponent & $\sigma_{\max }$ & calculated maximum stress \\
\hline$N_{i}$ & number of cycles to initiate the cracking & $\Delta T$ & temperature variation \\
\hline$N_{n}$ & number of crack junctions & $\Delta T_{c}$ & critical temperature amplitude \\
\hline$N_{t}$ & total number of cycles & $\Delta \varepsilon_{i}$ & critical strain difference \\
\hline$P(A)$ & size frequency distribution of the heat-checking cells & $\Delta \varepsilon_{m}$ & mechanical strain amplitude \\
\hline$P(C)$ & shape frequency distribution of the heat-checking cells & $\Delta \varepsilon_{p}$ & plastic strain amplitude \\
\hline$P(\theta)$ & orientation frequency distributions of micro-cracks & $\Delta \varepsilon_{s}$ & saturation strain difference \\
\hline$R$ & determination coefficient & $\Delta \varepsilon_{t}$ & difference of total strain between the oxide layer and \\
\hline$t$ & time & & the steel \\
\hline$T$ & temperature & $\Delta \sigma_{m}$ & mechanical stress amplitude \\
\hline$T_{\min }$ & minimum temperature of the thermal cycle & $\Phi_{\max }$ & maximum heat-flux density \\
\hline $\begin{array}{l}T_{\max } \\
W\end{array}$ & $\begin{array}{l}\text { maximum temperature of the thermal cycle } \\
\text { input energy per unit-area }\end{array}$ & & \\
\hline
\end{tabular}

bulk, which is at a lower temperature. Therefore, the surface undergoes compressive strains and subsequent stresses [4-6,14]. During ejection of parts, the working surface is rapidly cooled, in particular when a cooling system is employed. The "free" contraction of the surface is again constrained by the bulk, that stands now at higher temperatures. Thus, the surface is stretched under tensile thermal stresses. However, as the modulus of elasticity increases when the temperature decreases, if any plastic shielding occurs, its amplitude would be lower than at higher temperature (e.g. $T_{\max }$ ) and can be neglected in many conditions.

Testing of real components under service conditions is expensive. Laboratory in-house TF experiments are generally developed to assess the behaviour of materials $[4,7,15]$. Different unconstrained specimens (with various sizes and geometries) and heating and cooling systems are used. Also, tests are conducted on the basis of a "standard in-house" thermal cycle, i.e. a variation of the temperature vs. time compatible with the design requirements and test facility available [3-7,12]. The direct measurement of thermal and mechanical strains in operation conditions is difficult [16]. The thermo-mechanical history seen by the specimen must be calculated by appropriate constitutive laws and an elasto-visco-plastic thermomechanical modelling [4-6,9]. However, a non-linear thermomechanical analysis of industrial tools is often time-consuming, and one can use linear thermo-elastic calculations. We have previously proposed a normalized approach for assessing the heat-transfer and thermo-elastic stresses under transient conditions. It was shown that our laboratory TF test and the data produced can be reliably up-scaled to analyze and/or design tools in HPDC [17].

It is very common and straightforward to use the maximal temperature $T_{\max }$ as a damage parameter. In fact, the temperature per see is not a cracking criterion. The temperature (and more specifically $T_{\max }$ ) can undoubtedly contribute to form oxidation and corrosion products, and also, by coupling with mechanical loading, initiate and propagate cracks. By considering a uniaxial thermo-elastic case for the sake of simplification, the mechanical strain amplitude $\left(\Delta \varepsilon_{m}\right)$ and the stress amplitude $\left(\Delta \sigma_{m}\right)$ can be calculated as:

$$
\begin{aligned}
\Delta \varepsilon_{m} & \left.=\varepsilon_{\max }-\varepsilon_{\min }\right)=\alpha \cdot \Delta T, \text { and thus } \Delta \sigma_{m}\left(=\sigma_{\max }-\sigma_{\min }\right) \\
& =\alpha \cdot E \cdot \Delta T,
\end{aligned}
$$

where $\alpha$ is the mean thermal expansion, $\Delta T$ is the temperature amplitude $\left(\Delta T=T_{\max }-T_{\min }\right)$, and $E$ is the mean modulus of elasticity. Therefore, these are the "mechanical" strains and stresses that must be considered as criteria for crack initiation and propagation [15].

This paper deals with the influence of the TF test conditions on the microscopic heat-checking pattern formed on the surface of a $\mathrm{X} 38 \mathrm{CrMoV} 5$ steel specimen. The effects of the initial hardness of the steel, the maximum temperature and the heating rate of the thermal cycle on the crack density and the network morphology, are reported. We have previously shown that the evolution of the microscopic heat-checking density vs. number of cycles is sigmoidal, and the micro-crack density achieves rapidly an asymptotic saturated value in the "stabilized regime" [18]. The saturated heat-checking density is here related to the maximum heat-flux density and to the TF strains and stresses generated in the base steel. Crack propagation aspects and detailed post-mortem crosssections observations are reported in $[6,19]$.

\section{Experimental procedures}

\subsection{Thermal fatigue experiments}

Thermal fatigue (TF) tests were performed on a X38CrMoV5 (AISI H11) tool steel, quenched and double tempered to achieve a martensitic structure with either 42 or 47 HRC hardness. The chemical composition is given in Table 1 . The hollow cylindrical shaped specimens, with an inner diameter of $10 \mathrm{~mm}$ and an outer diameter of $30 \mathrm{~mm}$, have a wall thickness of $10 \mathrm{~mm}$ in the useful area of $40 \mathrm{~mm}$ length (Fig. 1). The external surface was mechanically polished to a mean arithmetic roughness $\left(R_{a}\right)$ close to $0.02 \mu \mathrm{m}$. The thermal fatigue rig (Fig. 2a) consists of an induction heating system, using a CELES-25 kW high frequency generator

Table 1

Chemical composition of X38CrMoV5 (AISI H11) steel.

\begin{tabular}{llllllllll}
\hline Element & $\mathrm{C}$ & $\mathrm{Cr}$ & $\mathrm{Mo}$ & $\mathrm{V}$ & $\mathrm{Si}$ & $\mathrm{Mn}$ & $\mathrm{S}$ & $\mathrm{P}$ & $\mathrm{Fe}$ \\
\hline Weight (\%) & 0.396 & 5.05 & 1.25 & 0.47 & 0.94 & 0.36 & $<0.003$ & 0.009 & Bal. \\
\hline
\end{tabular}


$(100-400 \mathrm{kHz})$. An induction frequency of $115 \mathrm{kHz}$ was used, resulting in a very fast heating of a thin surface layer of the specimen due to the induction "skin effect". The external surface is aircooled by natural convection. During the test, the specimen is continuously internally cooled by cold water circulating with a flow rate of $20 \mathrm{l} / \mathrm{min}$ (Fig. 2b). The temperature of the specimen is measured by a K-type thermocouple with a wire diameter of $0.1 \mathrm{~mm}$, spot welded to the external surface in the middle of the "gauge area" (central part of $20 \mathrm{~mm}$ length, where the thermal gradient is lower than $1^{\circ} \mathrm{C} / \mathrm{mm}$ ) [6,19].

Various thermal cycles are performed, with a minimal temperature $\left(T_{\min }\right)$ fixed to $100{ }^{\circ} \mathrm{C}$ (Table 2). The maximum temperature $\left(T_{\max }\right)$ of the thermal cycle varied from 550 to $685^{\circ} \mathrm{C}$ (Fig. 3a). The heating time $(h t)$ is controlled by adjusting the power of the induction generator between $60 \%$ to $100 \%$ of the full generator load capacity. For the tests with a maximum temperature of $650{ }^{\circ} \mathrm{C}, \mathrm{ht}$ ranged from 1.2 to $6.5 \mathrm{~s}$ (Fig. $3 \mathrm{~b}$ ), leading to very different mean heating rates $\left(85^{\circ} \mathrm{C} \mathrm{s}^{-1} \leqslant h r \leqslant 458{ }^{\circ} \mathrm{C} \mathrm{s}^{-1}\right)$, as indicated in Table 2 . The maximum heat-flux density applied at the surface of the specimen is related to the test conditions (Table 2), and mainly to the mean heating rate $\left(2.13 \mathrm{MW} \mathrm{m}^{-2} \leqslant \Phi_{\max } \leqslant 4.95 \mathrm{MW} \mathrm{m}^{-2}\right)$. For each thermal cycle, the cooling time (ct) is adjusted to achieve $T_{\min }$ on the specimen surface. Therefore, the cooling rate $(c r)$ does not change much from one test to another, varying between $18{ }^{\circ} \mathrm{C} \mathrm{s}^{-1}$ and $33^{\circ} \mathrm{C} \mathrm{s}^{-1}$. In order to investigate the evolution of the crack pattern on the surface of the specimen, the TF experi- ments were regularly stopped: every 500 or 1000 cycles until 3000 cycles, then every 2000 or 2500 cycles up to 15,000 cycles, and finally every 10,000 cycles right up to the end of the test $[6,19]$. In Table 2 are given, for each TF test, the interruption cycle when the micro-cracks are first detected, and the last interruption cycle to the end of the test, when the macro-crack are well propagated.

\subsection{Image analysis of the crack pattern}

After each cycling interruption, the surface of the specimen was observed with a Scanning Electron Microscope (SEM), using a backscattering electron detector and a magnification sufficiently high to reveal the micro-cracks $(\times 250)$. A randomly selected area of about $1 \mathrm{~mm}^{2}$ (located in the centre of the "gauge area") is then reconstructed by assembly a matrix of $(3 \times 3)$ images, leading to a high resolution cartography $(0.5 \mu \mathrm{m} / \mathrm{pixel})$ representing the crack pattern. Using the commercial image analysis Aphelion ${ }^{\circledR}$ software (ADCIS), the micro-cracks are segmented with an algorithm including pre-processing techniques, Boolean operations, and mathematical morphology transformations. The heat-checking density $\left(\rho_{h c}\right.$, expressed in $\mathrm{mm}^{-1}$ ) was then defined as the cumulated crack length per unit area. Individual analysis of both crack branches and heat-checking cells provides a full statistical description of the geometrical and morphological characteristics of the crack pattern [18].

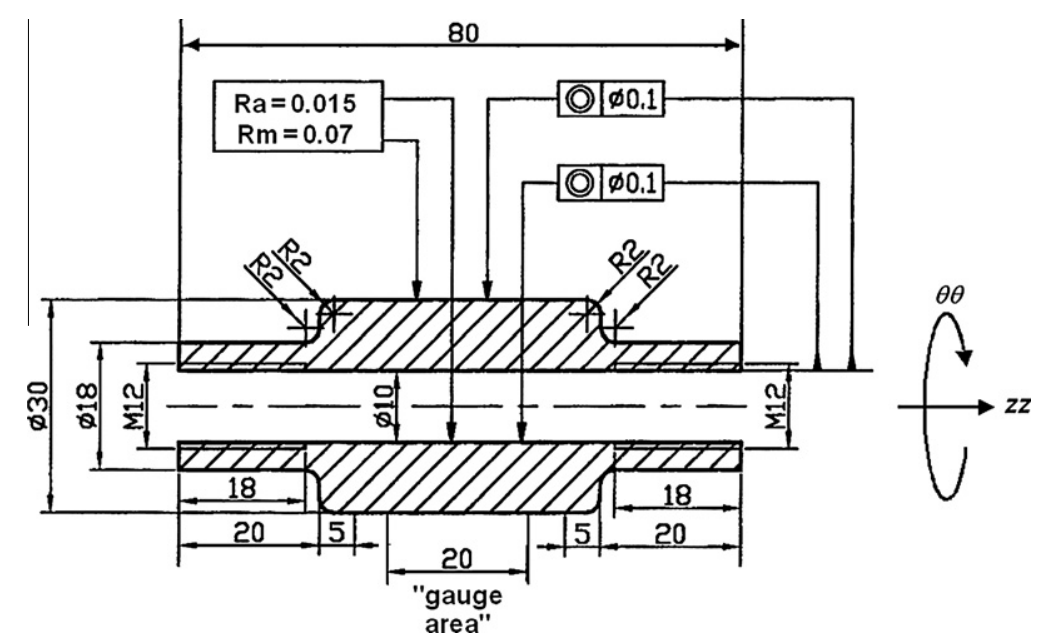

Fig. 1. Specimen geometry (the longitudinal and circumferential axis are respectively noted " $z z$ " and “ $\theta \theta$ ").
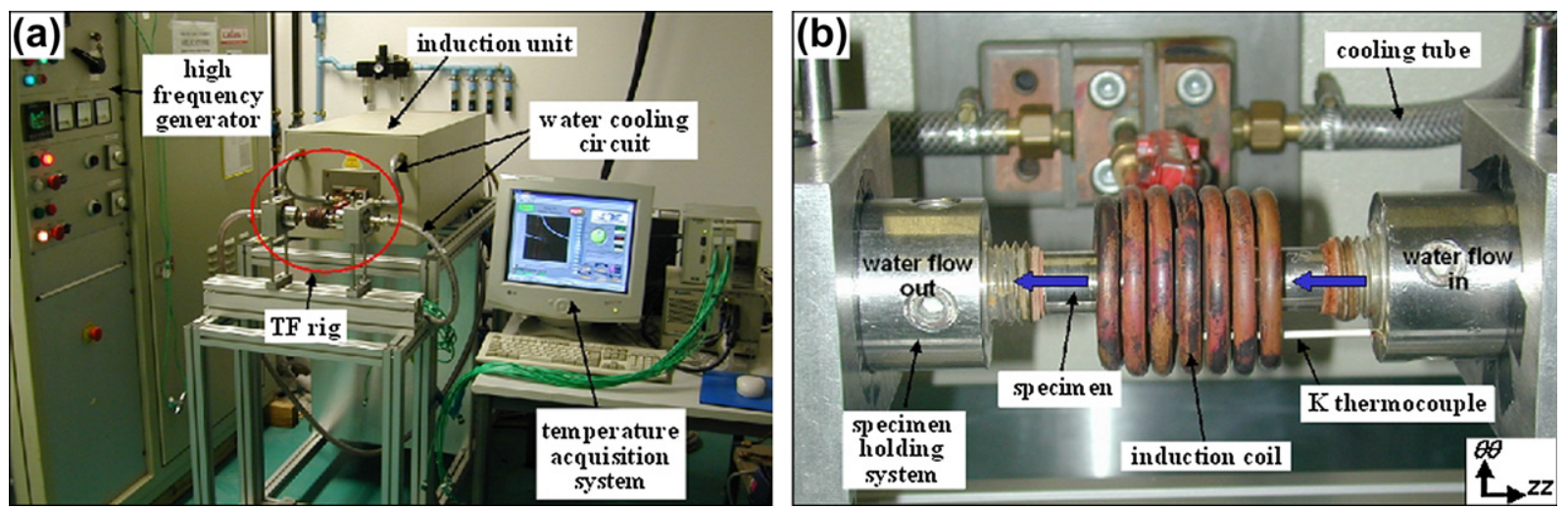

Fig. 2. Thermal fatigue rig: (a) general view; (b) induction coil and specimen. 
Table 2

Thermal cycles used in the TF tests for $47 \mathrm{HRC}$ treated X38CrMoV5 (only tests 3, 5 and 9 were performed on 42 HRC heat-treated steels).

\begin{tabular}{|c|c|c|c|c|c|c|c|c|}
\hline \multirow[t]{2}{*}{ No. test } & \multicolumn{2}{|l|}{ Thermal cycle } & \multicolumn{2}{|c|}{ Heating period } & \multirow{2}{*}{$\begin{array}{l}\text { Maximum heat-flux } \\
\text { density } \Phi_{\max }\left(\mathrm{MW} \mathrm{m}^{-2}\right)\end{array}$} & \multicolumn{2}{|c|}{ Cooling period } & \multirow{2}{*}{$\begin{array}{l}\text { First and last cycling stops } \\
\text { (number of cycles) }\end{array}$} \\
\hline & $T_{\min }-T_{\max }\left({ }^{\circ} \mathrm{C}\right)$ & $\Delta T\left({ }^{\circ} \mathrm{C}\right)$ & $\begin{array}{l}\text { Duration } \\
h t(\mathrm{~s})\end{array}$ & $\begin{array}{l}\text { Mean rate } \\
h r\left({ }^{\circ} \mathrm{C} \mathrm{s}^{-1}\right)\end{array}$ & & $\begin{array}{l}\text { Duration } \\
\text { ct }(\mathrm{s})\end{array}$ & $\begin{array}{l}\text { Mean rate } \\
\operatorname{cr}\left({ }^{\circ} \mathrm{C} \mathrm{s}^{-1}\right)\end{array}$ & \\
\hline 1 & $100-550$ & 450 & 0.90 & 14.5 & 4.75 & 500 & 31 & $30,000-80,000^{a}$ \\
\hline 2 & $100-575$ & 475 & 0.95 & 14.8 & 4.84 & 500 & 32 & $5000-50,000$ \\
\hline 3 & $100-600$ & 500 & 1.0 & 15.0 & 4.85 & 500 & 33 & $2500-60,000$ \\
\hline 4 & $100-625$ & 525 & 1.1 & 16.0 & 4.93 & 477 & 33 & $10,000-50,000^{\mathrm{a}}$ \\
\hline 5 & $100-650$ & 550 & 1.2 & 17.0 & 4.95 & 458 & 32 & $1000-20,000$ \\
\hline 6 & $100-650$ & 550 & 2.0 & 20.0 & 3.93 & 275 & 28 & $1000-30,000$ \\
\hline 7 & $100-650$ & 550 & 3.7 & 22.0 & 2.78 & 149 & 25 & $2000-30,000$ \\
\hline 8 & $100-650$ & 550 & 6.5 & 30.0 & 2.13 & 85 & 18 & $3000-50,000$ \\
\hline 9 & $100-685$ & 585 & 1.6 & 22.0 & 4.75 & 366 & 27 & $500-3000$ \\
\hline
\end{tabular}

a Test is not interrupted in the early stages of crack initiation.
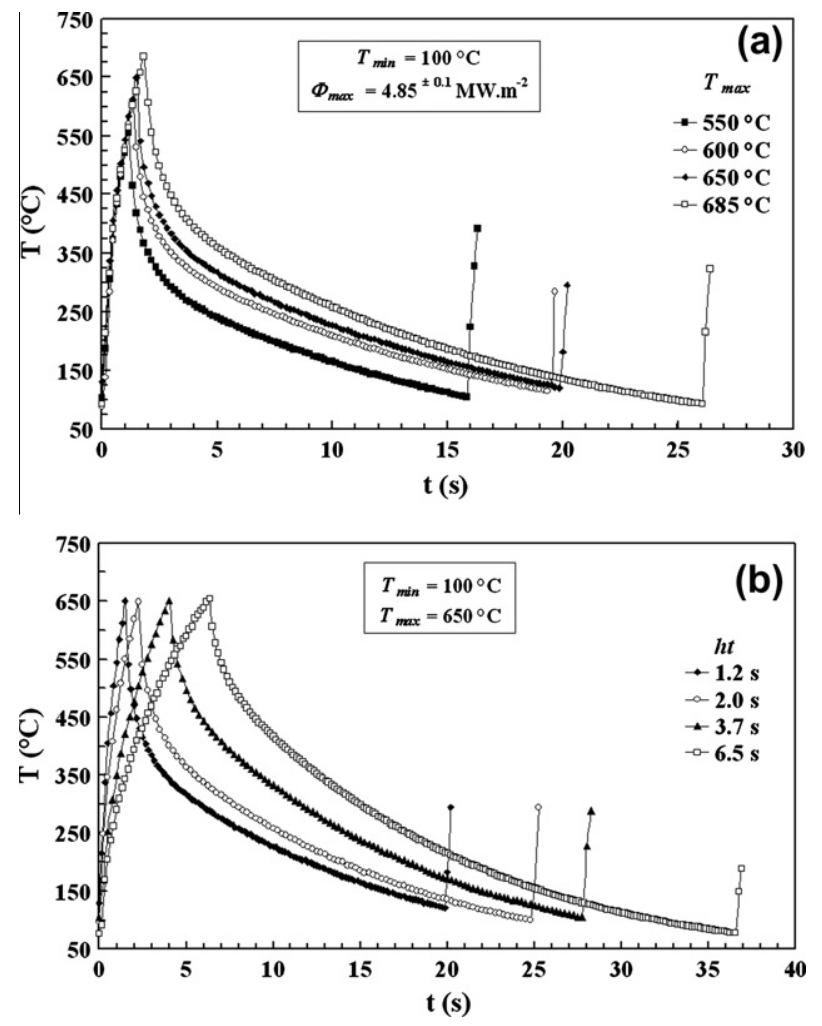

Fig. 3. Temperature-time profiles measured in the gauge area of the specimen, for various maximum temperatures $T_{\max }$ (a) and heating periods $h t(\mathrm{~b})$.

\section{Results}

\subsection{Effect of the maximum temperature $\left(T_{\max }\right)$ of the thermal cycle}

Fig. 4a shows the effect of the maximum temperature $\left(T_{\max }\right.$, investigated in the range between 550 and $685^{\circ} \mathrm{C}$ ) on the microscopic heat-checking aspect in the "gauge area" of the specimen. It should be specified that the heating period $(h t)$ of these tests increases from 0.9 to $1.6 \mathrm{~s}$ by increasing $T_{\max }$ from 550 to $685^{\circ} \mathrm{C}$. However, the estimated maximum heat-flux density $\left(\Phi_{\max }\right)$ imposed in the mid section of the specimen during the heating period is nearly constant at $4.85 \pm 0.1 \mathrm{MW} \mathrm{m}^{-2}$ (Table 2 ). The evolution of the heat-checking density vs. number of cycles presents a sigmoidal trend [18], rapidly reaching a saturated value after the crack pattern initiation (Fig. 4b). This saturated heat-checking density is almost $T_{\max }$-independent ( $\rho_{\text {sat }}=144 \mathrm{~mm}^{-1}$ on average, with a variation of $\pm 9 \%$ around this mean value), whereas the number of (a)
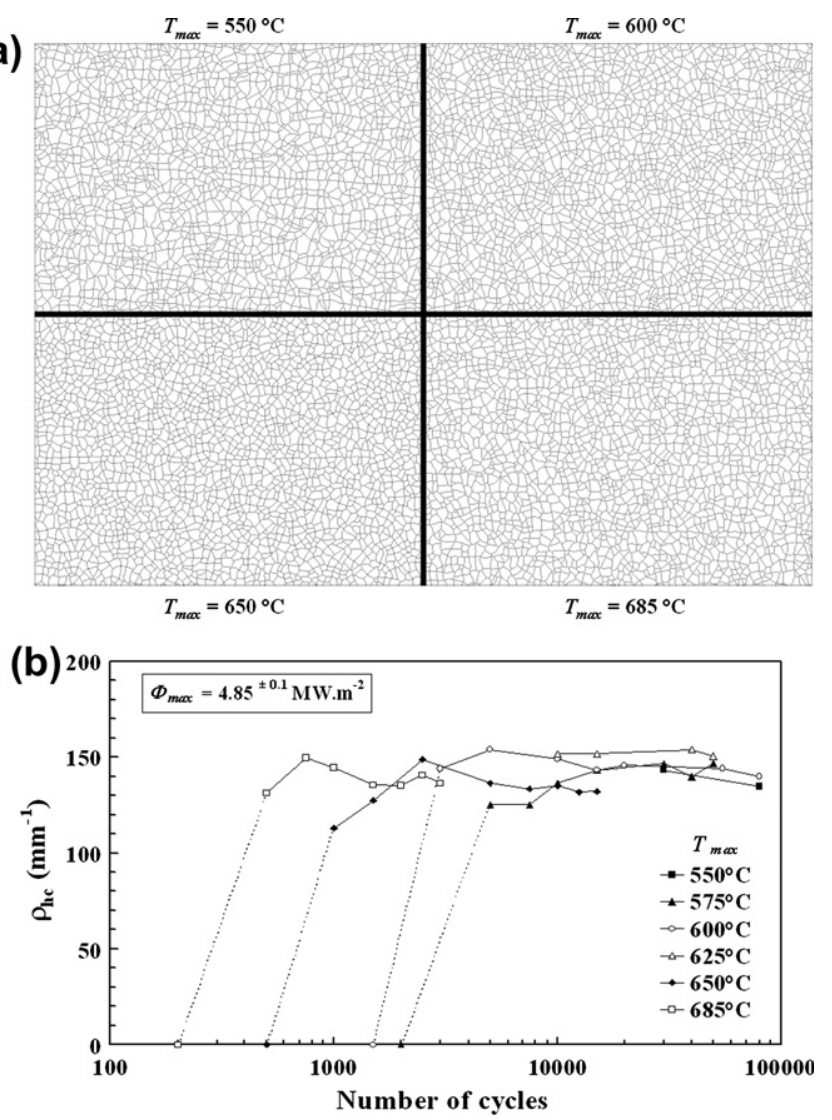

Fig. 4. Effect of the maximum temperature $\left(T_{\max }\right)$ on the microscopic heat-checking pattern in the gauge area of the specimen $\left(T_{\min }=100{ }^{\circ} \mathrm{C}, \Phi_{\max } \approx 4.85 \mathrm{MW} \mathrm{m}^{-2}\right):$ (a) increased sight of the cartographies showing the aspect of the saturated heatchecking for various $T_{\max }$; (b) evolution of the heat-checking density $\rho_{h c}$ vs. number of cycles.

cycles to initiate the micro-cracking seems to decrease with increasing $T_{\max }$. Whatever $T_{\max }$, rather similar size (Fig. 5a) and shape frequency distributions (Fig. 5b) are observed for the heatchecking cells in the saturated regime.

In Figs. 6a-c are plotted the roses of directions (cumulated length of micro-crack branches in a given direction) for three different $T_{\max }$. Two preferential orientations are revealed, at $0^{\circ}$ (corresponding to the longitudinal " $z z$ " axis) and $90^{\circ}$ (corresponding to the circumferential " $\theta \theta^{\circ}$ " axis). Four symmetry plans, along the $0^{\circ}$, $45^{\circ}, 90^{\circ}$ and $135^{\circ}$ directions, can be observed. The heat-checking network seems more isotropic when $T_{\max }$ exceeds $600^{\circ} \mathrm{C}$ (Fig. 6c). Table 3 indicates that whatever the maximum temperature of the 

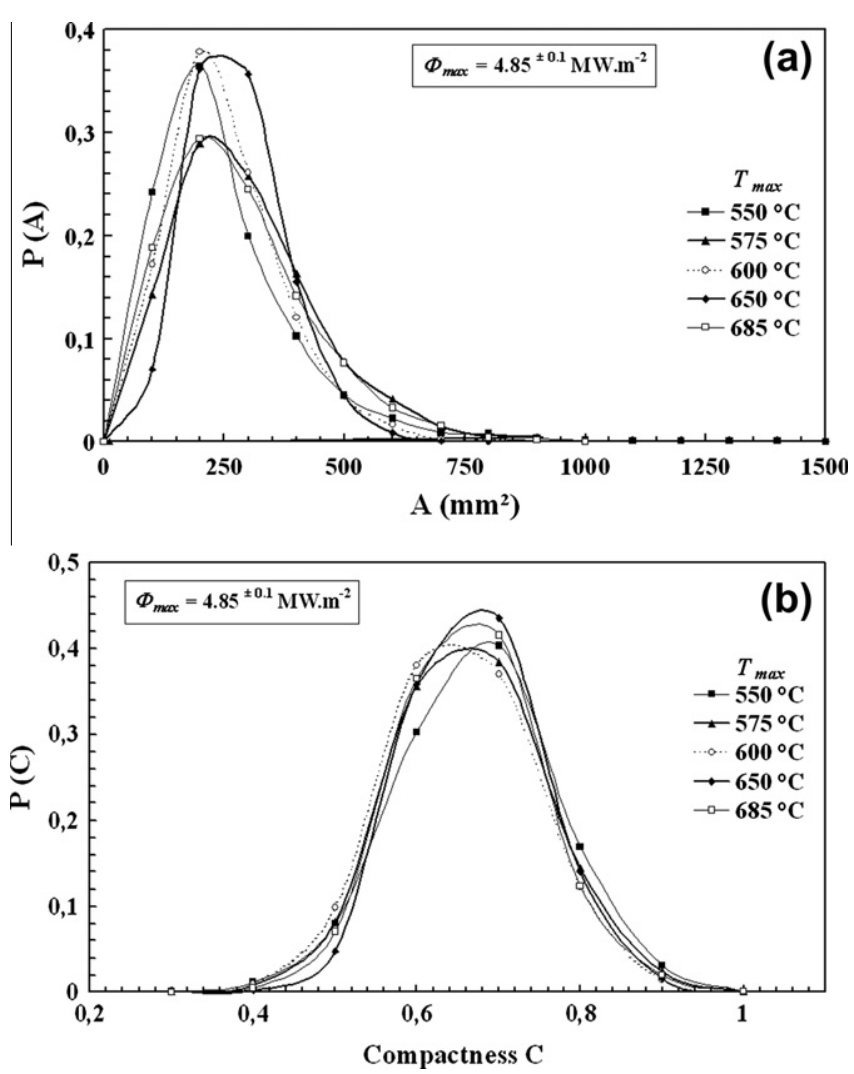

Fig. 5. Morphological characteristics of the microscopic heat-checking cells for various maximum temperatures $T_{\max }$, in the gauge area of the specimen (saturated regime): (a) size frequency distributions $P(A)$; (b) compactness frequency distributions $P(C)$.

test, a majority of trivalent crack junctions ( 3 branches per node class 3 ) is found (between $60 \%$ and $78 \%$, depending on $T_{\max }$ ), whereas tetravalent (class 4 ) and pentavalent (class 5) crack junctions are much less represented.

\subsection{Effect of the heating period (ht) of the thermal cycle}

For the tests performed with a $T_{\max }$ of $650^{\circ} \mathrm{C}$, the microscopic heat-checking aspect observed in the "gauge area" of the specimen differs depending on the heating period $h t$, investigated in the range from $1.2 \mathrm{~s}$ to $6.5 \mathrm{~s}$ (Fig. 7a). As indicated in Table 3, the estimated maximum heat-flux density $\left(\Phi_{\max }\right)$ ranges from $2.1 \mathrm{MW} \mathrm{m}^{-2}$ for the test with the slowest heating ( $h t=6.5 \mathrm{~s}$ and $h r=85^{\circ} \mathrm{C} \mathrm{s}^{-1}$ ) to $4.95 \mathrm{MW} \mathrm{m}^{-2}$ for the test with the fastest heating (with $h t=1.2 \mathrm{~s}$ and $h r=458^{\circ} \mathrm{C} \mathrm{s}^{-1}$ ). As shown in Fig. 7b, a similar sigmoidal trend is observed for the heat-checking density as a function of number of cycles. However, the saturated heat-checking density is almost tripled ( $\rho_{\text {sat }}$ increased from 50 to $140 \mathrm{~mm}^{-1}$ ) when the heating period $h t$ decreases from 6.5 to $1.2 \mathrm{~s}$, or in other words, when $\Phi_{\max }$ increases from 2.13 to $4.95 \mathrm{MW} \mathrm{m}^{-2}$. The number of cycles to crack initiation appears to be delayed when the heating period increases (Fig. 7b). The heat-checking cells exhibit very different size frequency distributions depending on $h t$ : faster heating cycles, achieved with greater maximum flux densities, produce smaller cells (Fig. 8a). In addition, these distribution curves are more scattered by increasing $h t$. The fastest heating cycles (with $\Phi_{\max }>3.8$ $\mathrm{MW} \mathrm{m}^{-2}$ ) present a normal Gaussian size distribution, while a negatively skewed distribution is observed for the slowest cycles $\left(\Phi_{\max }<2.9 \mathrm{MW} \mathrm{m}^{-2}\right)$. The shape frequency distributions of the heat-checking cells are also more scattered when the TF tests were performed using a low heating rate (Fig. $8 \mathrm{~b}$ ).

The frequency distributions of the micro-crack branch orientations present a bi-directional aspect, with two prevailing directions at $0^{\circ}$ and $90^{\circ}$ (Fig. 9). Irrespectively of the heating period of the thermal cycle, the heat-checking patterns are close to trivalent networks, with a large majority of class 3 crack-junctions (between $78 \%$ and $87 \%$ ), as reported in Table 3 .

\subsection{Effect of the initial hardness of the steel}

Some TF tests (see Table 2) have also been performed on steel specimens with an initial hardness of 42 HRC. As shown in Figs. 10a and b, a very similar trend was observed for the heatchecking density $\rho_{h c}$ vs. the number of cycles, regardless of the hardness of the steel and the maximum temperature $\left(T_{\max }=650\right.$ and $\left.685^{\circ} \mathrm{C}\right)$.

Neither the saturated crack density, nor the number of cycles to crack initiation appear to be significantly affected by the initial hardness of steel.

In addition, the distribution of the crack junction classes are very similar for both hardness (Table 3 ). Therefore, it can be stated that the microscopic heat-checking is hardness-independent under these testing conditions.

\section{Discussion}

4.1. Dependence of the size of the heat-checking cells to heat-flux density

It is usually claimed that there is a critical temperature range $\Delta T_{c}$ for the crack initiation of "brittle materials" (elastic rupture behaviour), such as oxide scale [20] or ceramics [21]. Korneta et al. investigated the cracking of thermal shocked ceramics from
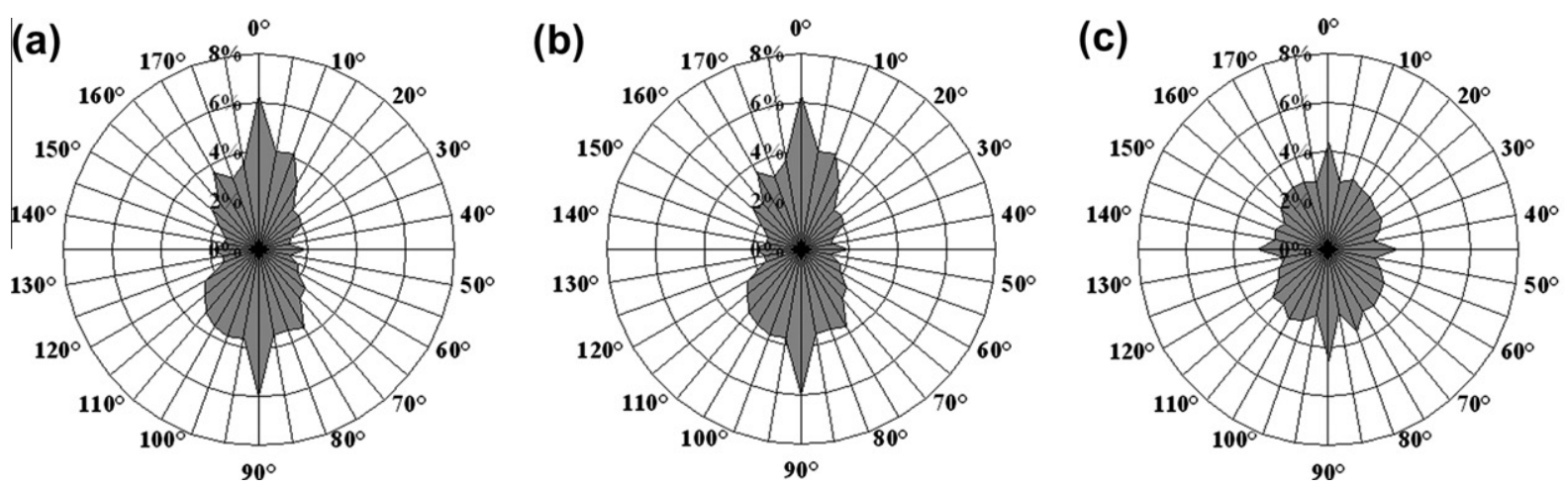

cumulated
crack length

Fig. 6. Rose of directions of micro-crack branches (cumulated length vs. $\theta$ ) for various maximum temperatures: $T_{\max }=550{ }^{\circ} \mathrm{C}(\mathrm{a}) ; T_{\max }=600{ }^{\circ} \mathrm{C}(\mathrm{b}) ; T_{\max }=650{ }^{\circ} \mathrm{C}(\mathrm{c})$. 
Table 3

Distribution of the trivalent (class 3), tetravalent (class 4) and pentavalent (class 5) crack junctions in the microscopic saturated heat-checking pattern produced by different thermal fatigue test conditions on 42 and 47 HRC heat-treated steel specimens.

\begin{tabular}{|c|c|c|c|c|c|c|c|c|}
\hline \multirow[t]{2}{*}{ TF test } & \multirow[t]{2}{*}{ Steel hardness (HRC) } & \multirow[t]{2}{*}{ Maximum temperature $T_{\max }\left({ }^{\circ} \mathrm{C}\right)$} & \multirow[t]{2}{*}{ Heating time $t(\mathrm{~s})$} & \multirow[t]{2}{*}{ Number of cycles $N_{t}$} & \multirow[t]{2}{*}{ Number of crack junctions $N_{n}$} & \multicolumn{3}{|c|}{$\begin{array}{l}\text { Relative percentage } \\
\text { of crack junction } \\
\text { classes }\end{array}$} \\
\hline & & & & & & 3 & 4 & 5 \\
\hline 1 & 47 & 550 & 0.90 & 80,000 & 4777 & 64.0 & 26.7 & 9.3 \\
\hline 2 & 47 & 575 & 0.95 & 50,000 & 5563 & 60.5 & 28.9 & 10.6 \\
\hline 3 & 47 & 600 & 1.0 & 80,000 & 4818 & 70.8 & 22.6 & 6.6 \\
\hline 4 & 47 & 625 & 1.1 & 50,000 & 6253 & 67.5 & 24.2 & 8.3 \\
\hline 5 & 42 & 650 & 1.2 & 20,000 & 5065 & 77.7 & 16.9 & 5.6 \\
\hline 6 & 47 & 650 & 2.0 & 30,000 & 3388 & 77.7 & 16.0 & 6.3 \\
\hline 7 & 47 & 650 & 3.7 & 30,000 & 1265 & 87.1 & 9.6 & 3.2 \\
\hline 8 & 47 & 650 & 6.5 & 50,000 & 890 & 77.8 & 15.3 & 7.0 \\
\hline \multirow[t]{2}{*}{9} & 42 & 685 & 1.6 & 3000 & 6131 & 69.2 & 21.5 & 9.3 \\
\hline & 47 & 685 & 1.6 & 3000 & 6524 & 69.1 & 20.4 & 10.6 \\
\hline
\end{tabular}
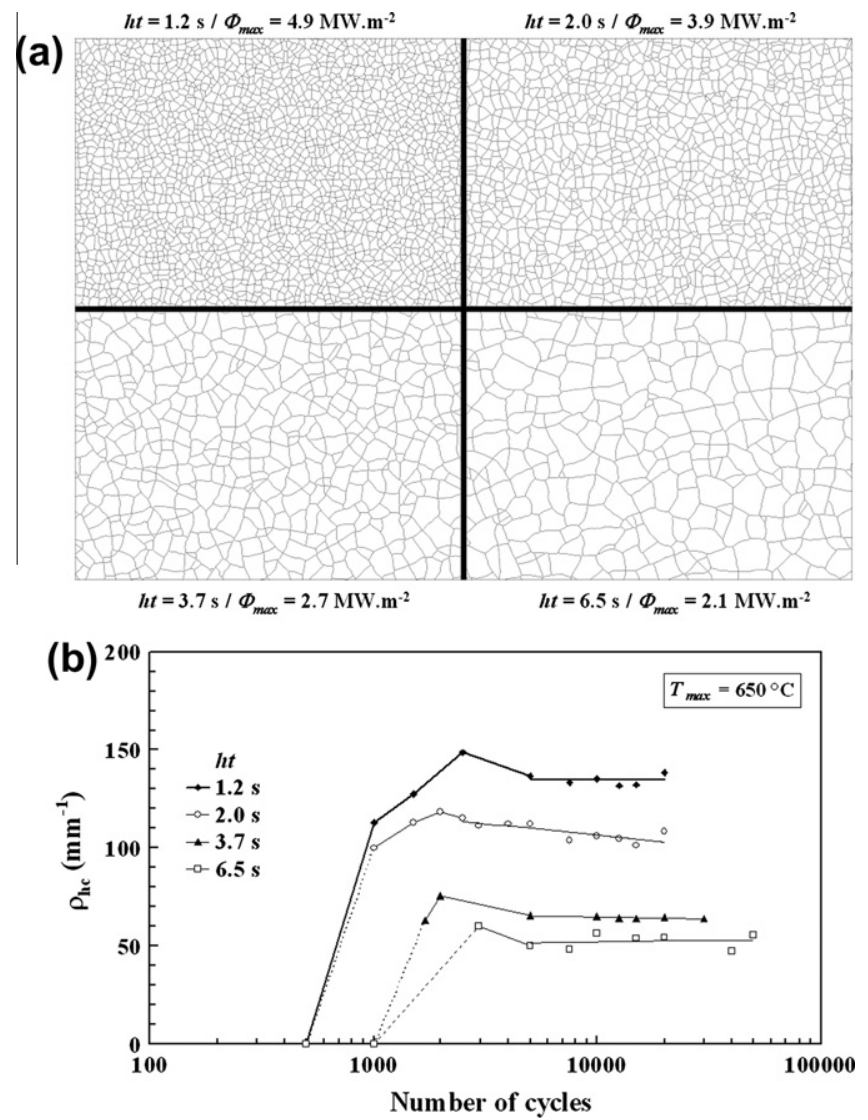

Fig. 7. Effect of the heating time ht on the microscopic heat-checking, in the gauge area of the specimen $\left(T_{\min }=100^{\circ} \mathrm{C}, T_{\max }=650^{\circ} \mathrm{C}, \Phi_{\max } \approx 4.85 \mathrm{MW} \mathrm{m}{ }^{-2}\right)$ : (a) increased sight of the cartographies showing the aspect of the saturated heatchecking for various $h t$; (b) evolution of the heat-checking density $\rho_{h c}$ vs. number of cycles.

various maximum temperatures ranging from 300 to $700{ }^{\circ} \mathrm{C}$, and observed that the crack density changes with the temperature range $\Delta T$, when $\Delta T>\Delta T_{c}$ [21]. However, Fig. 11a shows that the saturated heat-checking density $\rho_{\text {sat }}$ measured on our TF specimens in the stabilized regime does not vary much $\left(\rho_{\text {sat }}=144 \pm 13\right.$ $\mathrm{mm}^{-1}$, i.e. a difference of $\pm 9 \%$ ) by changing $T_{\max }$ ( and therefore $\Delta T$ ). On the other hand, $\rho_{\text {sat }}$ increases by increasing the heating rate $h r$ (or decreasing the heating period ht (Fig. 11b). It should be highlighted that $h r$ is a mean rate calculated by the ratio of the temperature amplitude $\Delta T$ to the heating period $h t$ of the thermal cycle:
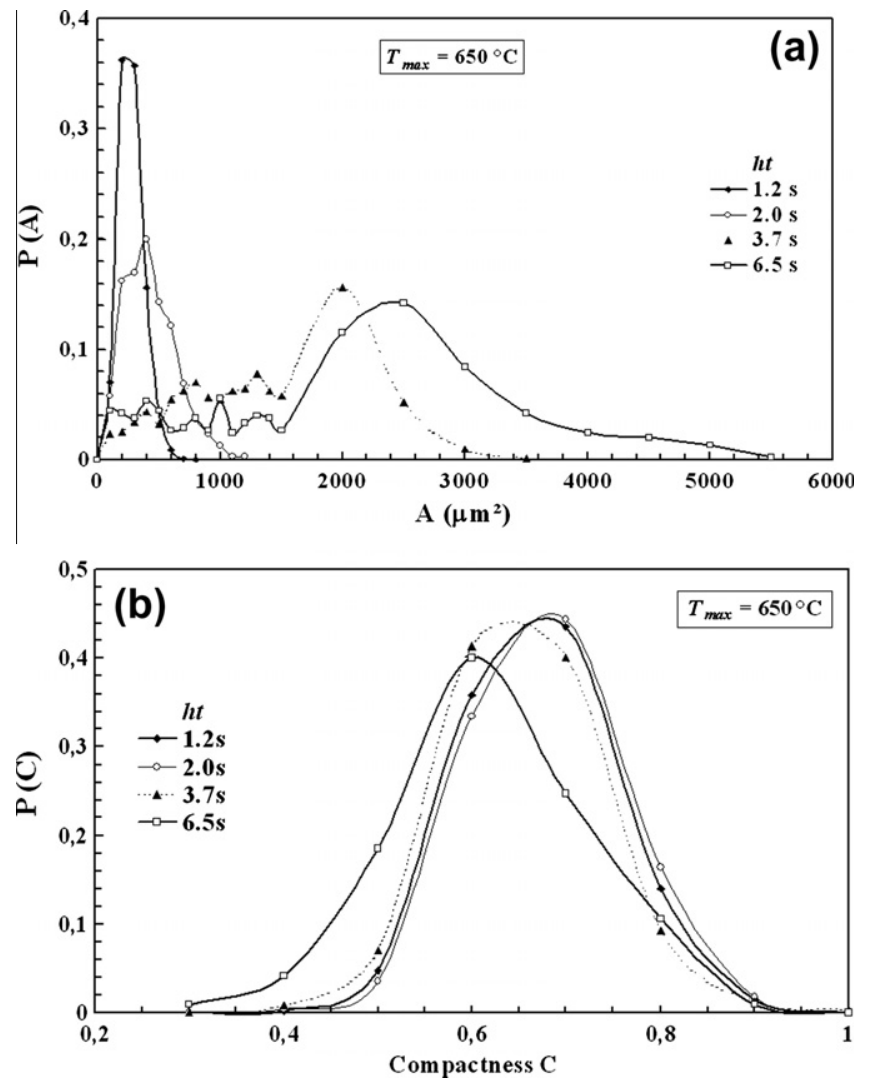

Fig. 8. Morphological characteristics of the microscopic heat-checking cells for various heating times $h t$, in the gauge area of the specimen (saturated regime): (a) size frequency distributions $P(A)$; (b) compactness frequency distributions $P(C)$.

$h r=\Delta T / h t=\left(T_{\max }-T_{\min }\right) / h t$.

This approximate estimation may explain the scattering observed on the best-fit curve (power law) of Fig. 11b ( $\rho_{\text {sat }}$ vs. $h r$ ) when $h r$ is greater than $300{ }^{\circ} \mathrm{C} / \mathrm{s}$, although the correlation coefficient of the regression curve $(R=0.970)$ is relatively high. In addition, the heating period and heat-flux density are inter-dependent, if all other influencing parameters (such as the specimen geometry, $T_{\min }$, and $T_{\max }$ ) remain unchanged. By plotting the saturated microscopic heat-checking density $\rho_{\text {sat }}$ as a function of the maximum heat-flux density $\Phi_{\max }$ (Fig. 12) for all thermal cycling conditions, a remarkable linear relationship is found:

$\rho_{\text {sat }}=33.6 \Phi_{\max }-23.2$. 


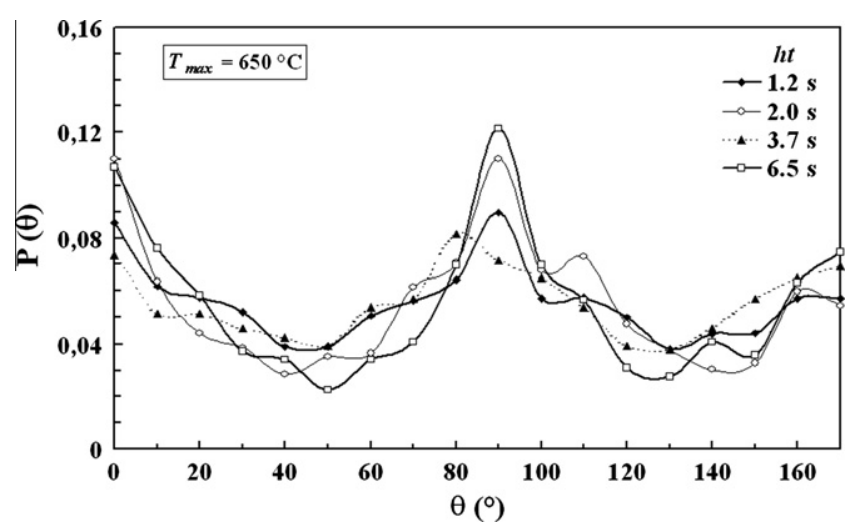

Fig. 9. Frequency distributions $P(\theta)$ of micro-crack branch orientations (cumulated length vs. $\theta$ ), for various heating times $h t$.
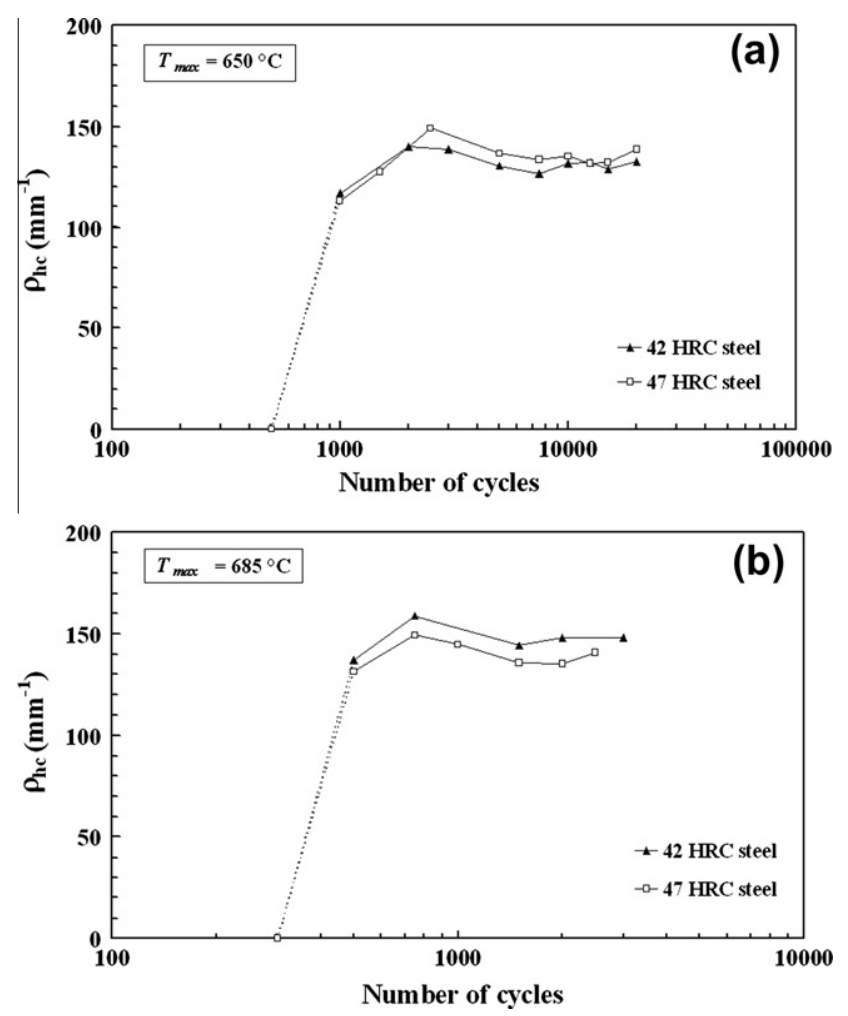

Fig. 10. Evolution of the microscopic heat-checking density $\rho_{h c}$ vs. number of cycles, in the gauge area of the specimen, for 42 and 47 HRC treated steels: (a) $T_{\max }=650{ }^{\circ} \mathrm{C}, h t=1.2 \mathrm{~s}$; (b) $T_{\max }=685^{\circ} \mathrm{C}, h t=1.6 \mathrm{~s}$.

This correlation indicates that the saturated heat-checking density increases proportionally to the maximum heat-flux density, establishing a strong "size dependence" of the microscopic heatchecking cells with $\Phi_{\max }$ in the investigated range $\left(2 \mathrm{MW} \mathrm{m}^{-2}<-\right.$ $\Phi_{\max }<5 \mathrm{MW} \mathrm{m}^{-2}$ ). However, it could be expected that $\rho_{\text {sat }}$ might not infinitively increase by increasing $\Phi_{\max }$, and may achieve a certain ultimate limit. Thus, a logarithmic law might be physically more consistent, although the determination coefficient $(R=0.955)$ is slightly lower than for Eq. (2) $(R=0.971)$. Unfortunately, due to limitation of our test facility, tests with very high heat-flux densities could not be performed to experimentally assess this point.

In Fig. 13, the variation of $\rho_{\text {sat }}$ is reported as a function of the input energy per unit-area $(W)$ at the external surface of the specimen,
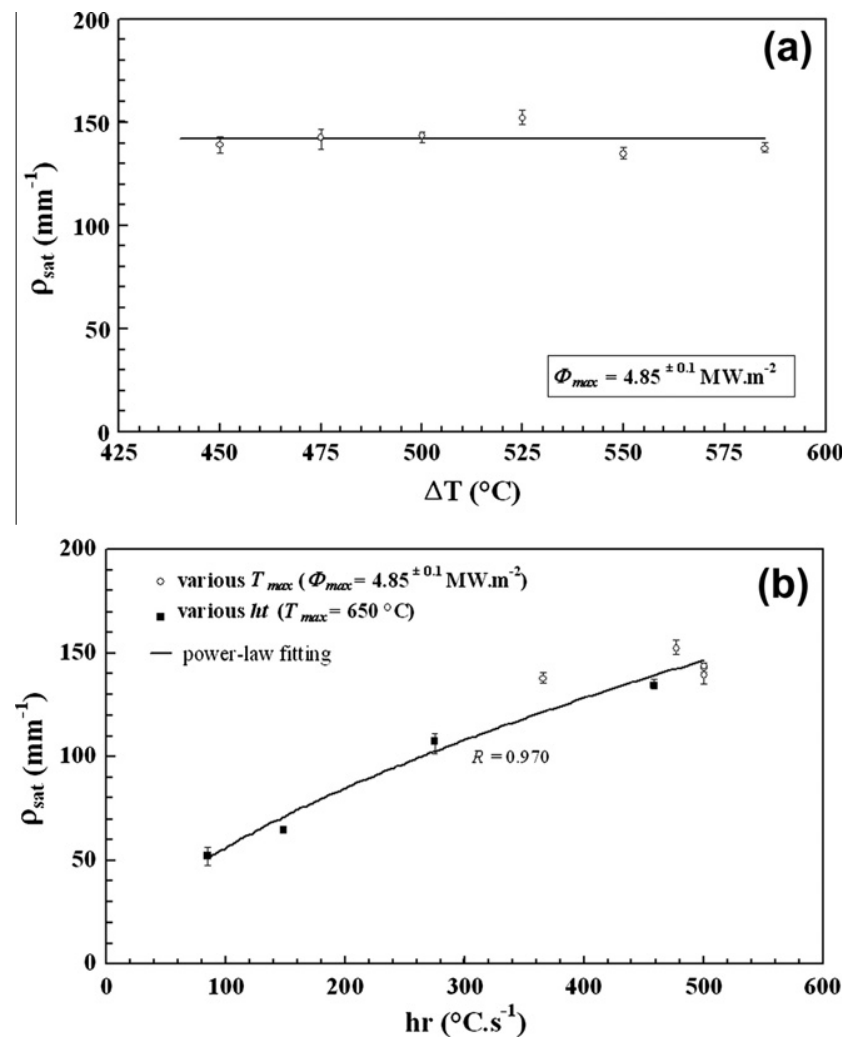

Fig. 11. Effect on the saturated heat-checking density $\rho_{\text {sat }}$ of the temperature range $\Delta T$ (a), and the heating rate $h r(\mathrm{~b})$ of the thermal cycle.

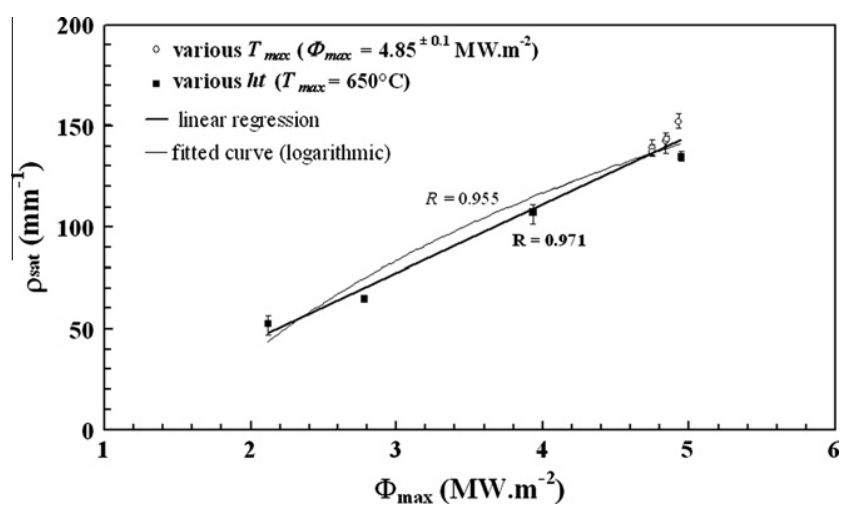

Fig. 12. Effect of the maximum heat-flux density $\Phi_{\max }$ applied during the heating period on the saturated heat-checking density $\rho_{\text {sat }}$.

which is roughly estimated by multiplying the maximum heat-flux density by the heating period. This curve better indicates that beyond a critical limit of the transmitted energy per unit-area $\left(W_{c}{ }^{-}\right.$ $\approx 3 \times 10^{3} \mathrm{~J} \mathrm{~mm}^{-2}$ ), the heat-checking density remains quasiunchanged. In fact, the oxide layer cannot dissipate the total thermo-mechanical dynamic energy imposed at the surface by self-constraint cracking, and therefore only a part of this energy is "sufficient" and contributes to the heat-checking. One can imagine that the oxide layer acts as a "thermo-mechanical dissipative barrier" material. Undissipated thermo-mechanical energy that is transmitted to the steel substrate, leads to propagate by thermal fatigue solicitations the micro-cracks initiated on the oxide-layer into the sub-layer steel. Repetition of such TF cycling can affect, in addition, the local properties of the steel (for example softening, highlighted by RT hardness measurements $[3,5]$ ), leading to thermal 


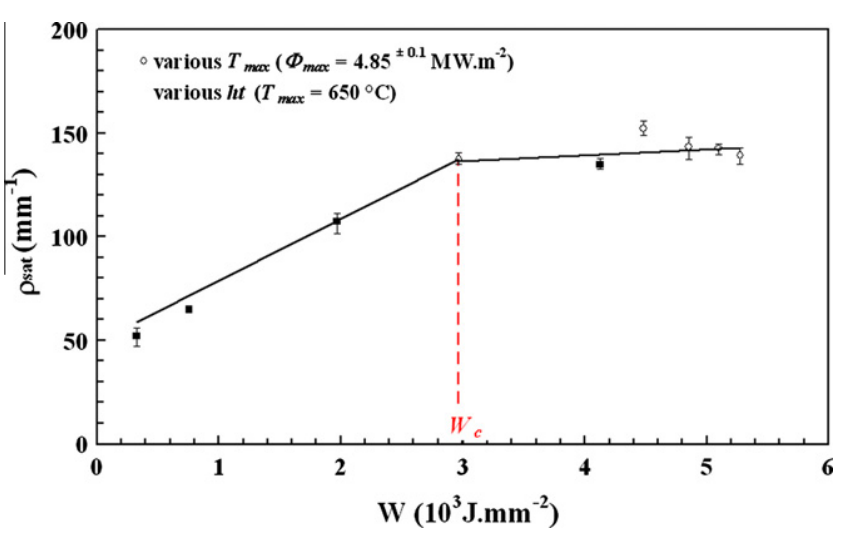

Fig. 13. Effect of the input energy per unit-area $W$ applied during the heating period on the saturated heat-checking density $\rho_{\text {sat }}$.

fatigue cracking. Indeed, beyond $W_{c}$, the TF macro-crack initiation life in base steel is reduced, and the crack growth rate is also increased $[6,19]$.

\subsection{Effect of thermal expansion mismatch on the saturated crack density}

Detailed microscopic observations on the surface of the TF specimens show that the oxide scale is actually formed of two layers of equal individual thickness $[18,19]$. For the sake of simplification, one can consider that the specimen is composed of a bi-lamellar composite, consisting of an equivalent oxide layer and the steel parent. This equivalent oxide layer is mainly constituted of an iron oxide $\left(\mathrm{Fe}_{2} \mathrm{O}_{3}\right)$ and a chromium oxide $\left(\mathrm{Cr}_{2} \mathrm{O}_{3}\right)$, with different coefficients of thermal expansion $\left(\alpha=14.9 \times 10^{-6} \mathrm{~K}^{-1}\right.$ and $7.3 \times 10^{-6} \mathrm{~K}^{-1}$, respectively) [22]. Considering an average coefficient of thermal expansion for the equivalent oxide layer, whose deformation is controlled mainly by its thermal expansion, the total strain in the oxide layer can be calculated as:

$\varepsilon_{t, o x}=\alpha_{o x} \cdot \Delta T=\left(\alpha_{\mathrm{Fe}_{2} \mathrm{O}_{3}}+\alpha_{\mathrm{Cr}_{2} \mathrm{O}_{3}}\right) \cdot\left(T_{\max }-T_{\min }\right) / 2$.

For the bulk steel, the total strain $\varepsilon_{t, s}$ was calculated by FEM analysis, using ABAQUS ${ }^{\mathrm{TM}}$ software and a thermo-elasto-plastic constitutive law [19]. Fig. 14a and b illustrate the effects of the TF conditions ( $\Delta T$ and $h t$ ) on the total strain in the equivalent oxide layer $\left(\varepsilon_{t, o x}\right)$ and in the sub-layer steel $\left(\varepsilon_{t, s}\right)$, and consequently on the strain difference $\Delta \varepsilon_{t}$ :

$\Delta \varepsilon_{t}=\varepsilon_{t, 0 x}-\varepsilon_{t, s}$.

Whatever the temperature variation $\Delta T$ of the test, the total strain in the oxide layer and in the steel shows quite similar trends, with an approximately constant difference $\Delta \varepsilon_{t}$ of $0.365 \pm 0.035 \%$ (Fig. 14a). Consequently, it can be claimed that $T_{\max }$ has no significant effect on the saturated heat-checking density, which shows similar values $\left(\rho_{\text {sat }}=144 \pm 13 \mathrm{~mm}^{-1}\right.$, as previously shown, Fig. 11) provided that the maximum heat-flux density applied during the heating period is equivalent $\left(\Phi_{\max }=4.85 \pm 0.1 \mathrm{MW} \mathrm{m}^{-2}\right)$. On the other hand, a variation in the heating time - which results in various $\Phi_{\max }$ values - affects the total strain only in the steel substrate, and not in the oxide layer (Fig. 14b). This implies a variation in the strain difference $\Delta \varepsilon_{t}$, leading to very different saturated heat-checking density $\left(47<\rho_{\text {sat }}<140 \mathrm{~mm}^{-1}\right)$. The strain difference represents in fact a local mechanical incompatibility generated by the thermal mismatch between two layers constituting the "composite material". This "mismatch strain" is therefore the main driving force leading to the cracking of the superficial oxide layer: the higher $\Delta \varepsilon_{t}$, the higher $\rho_{\text {sat }}$, as shown in Fig. 15.
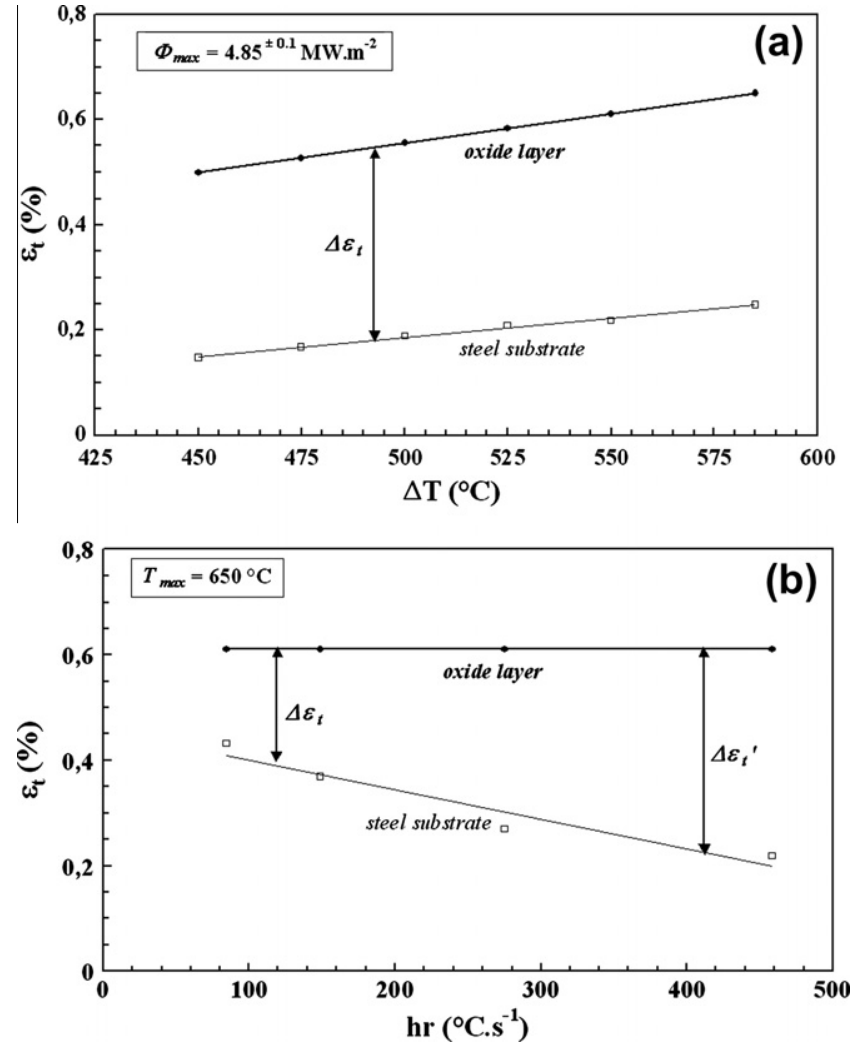

Fig. 14. Evolution of the calculated total strain $\varepsilon_{t}$, generated in the oxide layer and in the substrate, as a function of the temperature variation $\Delta T$ (a) and the heating time $h t$ (b) of the thermal cycle.

Nevertheless, the heat-checking density exhibits an asymptotic trend beyond a maximal critical $\Delta \varepsilon_{t}$ value (estimated at $0.35 \%$ ), which can be defined as a "saturation strain difference" $\left(\Delta \varepsilon_{s}\right)$ leading to a maximum value for the saturated crack density. In addition, it can be claimed that a total strain amplitude higher than $\Delta \varepsilon_{s}$ would result in crack opening and in-depth propagation into the parent steel $[6,19]$. The same conclusion was reached by Zhu et al., regarding the cracking behaviour of a $\mathrm{Cu}-\mathrm{Ni}$ multilayer deposited on a polyimide substrate subjected to bending [23]. By extrapolating the curve of Fig. 15 to a null crack density $\left(\rho_{\text {sat }}=0\right)$, one can approximately estimate the critical strain difference $\left(\Delta \varepsilon_{i}-\right.$ $\approx 0.13 \%$ ) below which no micro-cracking could initiate in the oxide layer [23].

As mentioned earlier, Korneta et al. have attributed the variation of the crack density observed on thermally shocked ceramics at various $T_{\max }$ to the temperature amplitude $\Delta T$ [21]. However, these authors did not consider the cooling rate, presumably because of the thermo-elastic time independent behaviour of such fragile materials. In fact, during the cooling period, $\Delta T$ generates thermo-elastic strains and associated stresses that damage the ceramic. Nonetheless, a thermo-elastic loading approach is not relevant for materials with an elasto-plastic or elasto-visco-plastic behaviour, such as metallic alloys. For example, it is reported that the crack spacing observed in the oxide scale formed on steels and metallic alloys under creep experiments, stabilizes to a saturated value after reaching equilibrium [22]. This saturation crack spacing (named " $L_{\text {sat }}$ ") and the saturated crack network density $\left(\rho_{\text {sat }}\right)$ reported here - that is proportional to the inverse of the mean crack spacing - are in fact two reciprocal damage criteria [24]. In addition, it should be mentioned that $\rho_{\text {sat }}$ is relevant to characterize multi-axial cracking (i.e. heat-checking), while $L_{\text {sat }}$ better describes macroscopic uniaxial cracking. The creep experiments reported by 


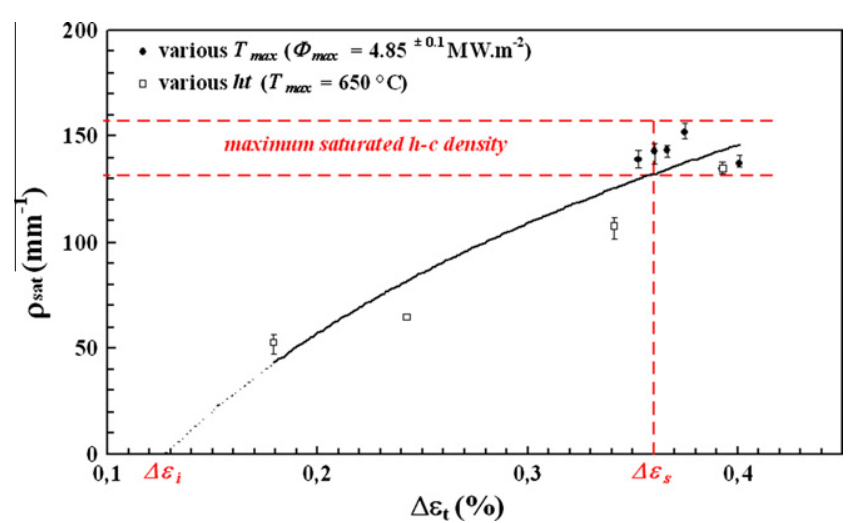

Fig. 15. Effect of the difference of total strain $\Delta \varepsilon_{t}$ between the oxide layer and the steel substrate $\left[\Delta \varepsilon_{t}=\varepsilon_{o x}-\varepsilon_{s}\right]$ on the saturated microscopic heat-checking density $\rho_{\text {sat }}$.

Schütze [22] have revealed that when the creep strain-rate of the substrate $d \varepsilon / d t$ increases, the saturation crack spacing $L_{\text {sat }}$ decreases (Fig. 16). By reporting the data from our experiments on the same figure, one can observe that the TF specimens present the same trend, even if the strain range is higher than under these creep experiments:

$L_{\text {sat }}=0.3904(d \varepsilon / d t)^{-0.418}$.

It can be noted that the strain rate exponent calculated from our curve is lower than $0.5(m=-0.418)$. This value is very close to those reported in creep experiments $(-0.33<m<-0.41)$ [22]. Under creep conditions, the oxide layer behaves as a quasi-elastic material constrained by a substrate having an elasto-visco-plastic behaviour. Schütze interpreted $L_{\text {sat }}$ as a "viscous sliding" due to the ability of the substrate steel to creep in the range of $10^{-8}$ to $10^{-6}$ strain rate (without specifying whether it is a secondary creep strain rate or not). Under the TF conditions investigated in this study, the behaviour of the sub-surface layer can be described to a lesser extent by a low strain time-dependant creep behaviour than by the frequency-dependent cyclic plasticity, even if the physically based phenomena of plastic cyclic softening and creep would be similar.

\subsection{Micro-crack initiation life}

It is observed that for a prescribed maximum heat-flux density, the estimated number of cycles $N_{i}$ to initiate microscopic

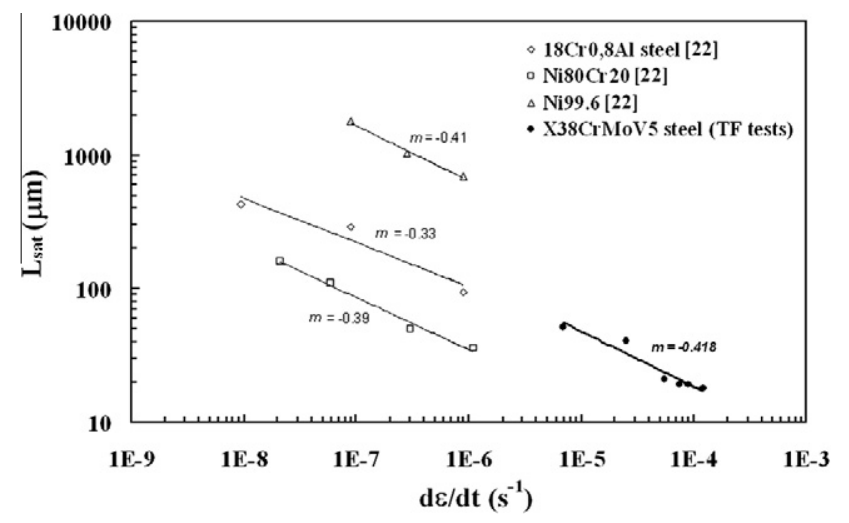

Fig. 16. Evolution of the saturation crack spacing $L_{\text {sat }}$ in the oxide scale as a function of the strain rate $d \varepsilon / d t$ of the substrate, for various metallic alloys under creep experiments [22] and thermal fatigue tests. heat-checking [18] is strongly dependent on the temperature amplitude of the thermal cycle: a higher $\Delta T$ leads to an earlier micro-crack initiation (Fig. 17a). In addition, Fig. 17b shows that for TF tests performed under the same $T_{\max }\left(600\right.$ and $\left.650{ }^{\circ} \mathrm{C}\right)$, the heat-checking life $N_{i}$ also changes with the heating rate: a slower $h r$ delays the crack initiation. It appears that different curves are obtained depending on $T_{\max }$, indicating that the dependence of $N_{i}$ with $h r$ would be more sensitive at high $T_{\max }$. However, this statement needs to be verified by additional tests, with different heating rates at $600{ }^{\circ} \mathrm{C}$ and/or $685^{\circ} \mathrm{C}$. It can be noted that a similar effect of $\Delta T$ and $h r$ was also observed - in larger number of cycles - on macro-crack initiation life, as reported in $[6,19]$.

It is generally stated that under stretching, an oxide layer or a thin film initiates cracking when it reaches a critical thickness $[20,24,25]$, and that beyond this critical thickness, the crack density increases with the thickness of the layer [24,25]. Based on thickness measurements of the oxide layer formed on our specimens after different numbers of cycles, a model was established to estimate the oxide thickness at a given cycle time $[6,19]$. For $T_{\max }>600^{\circ} \mathrm{C}$ and a large number of cycles, it has been shown that the oxide growth rate follows a parabolic law. The thickness of the oxide layer formed during the TF test is higher when the heating rate is slower, since the total oxidation time is longer. However, as mentioned above, $N_{i}$ is governed by the heating rate. For example, the test performed with a $T_{\max }$ of $650^{\circ} \mathrm{C}$ and a high heating rate $\left(h r=458^{\circ} \mathrm{C} . \mathrm{s}^{-1}\right.$ ) led to a shorter micro-crack initiation life (almost three time lower) than a test performed at the same $T_{\max }$ with a slower heating rate $\left(h r=85^{\circ} \mathrm{C} \mathrm{s}^{-1}\right)$, while the oxide scale was five times thicker in the second case (Fig. 17b).

In our TF experiments, the oxide thickness alone cannot be a consistent factor to explain the initial formation of the crack pattern. In fact, the cracking of the oxide scale is mainly governed by the strains and stresses induced in the specimen, due to the
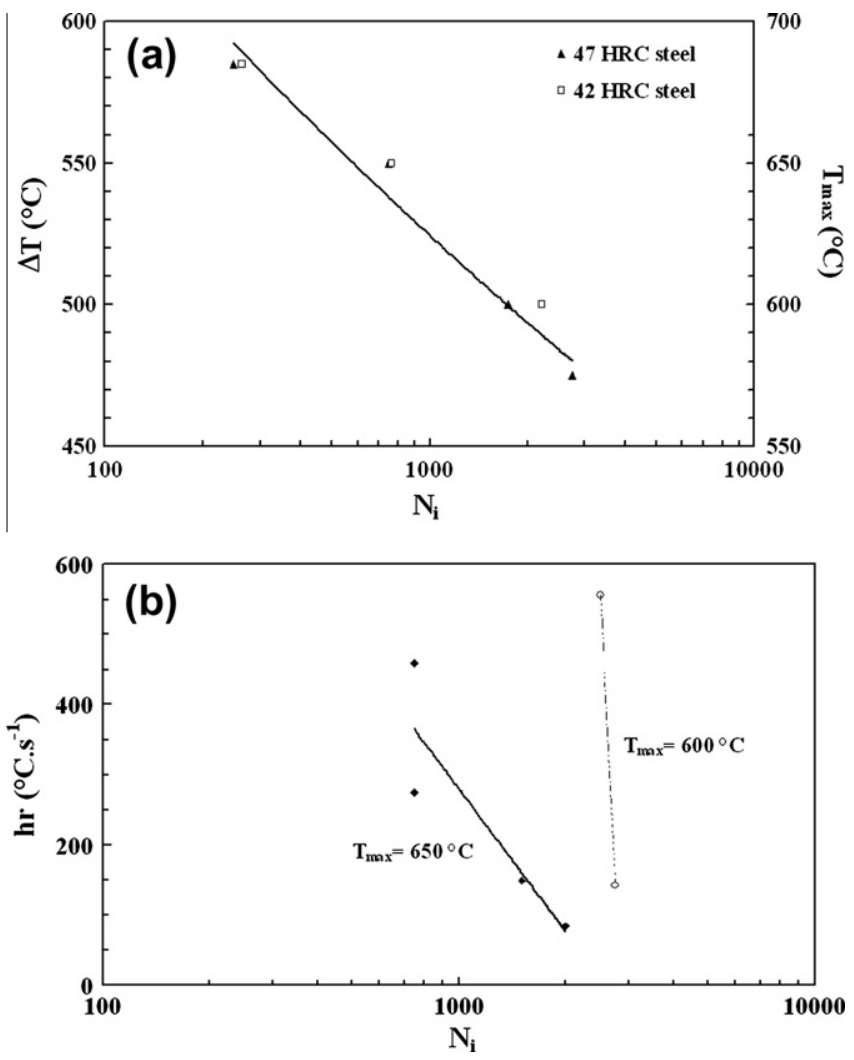

Fig. 17. Effect of the temperature variation $\Delta T$ (a) and of the heating rate $h r$ (b) on the number of cycles $N_{i}$ to initiate the microscopic heat-checking. 

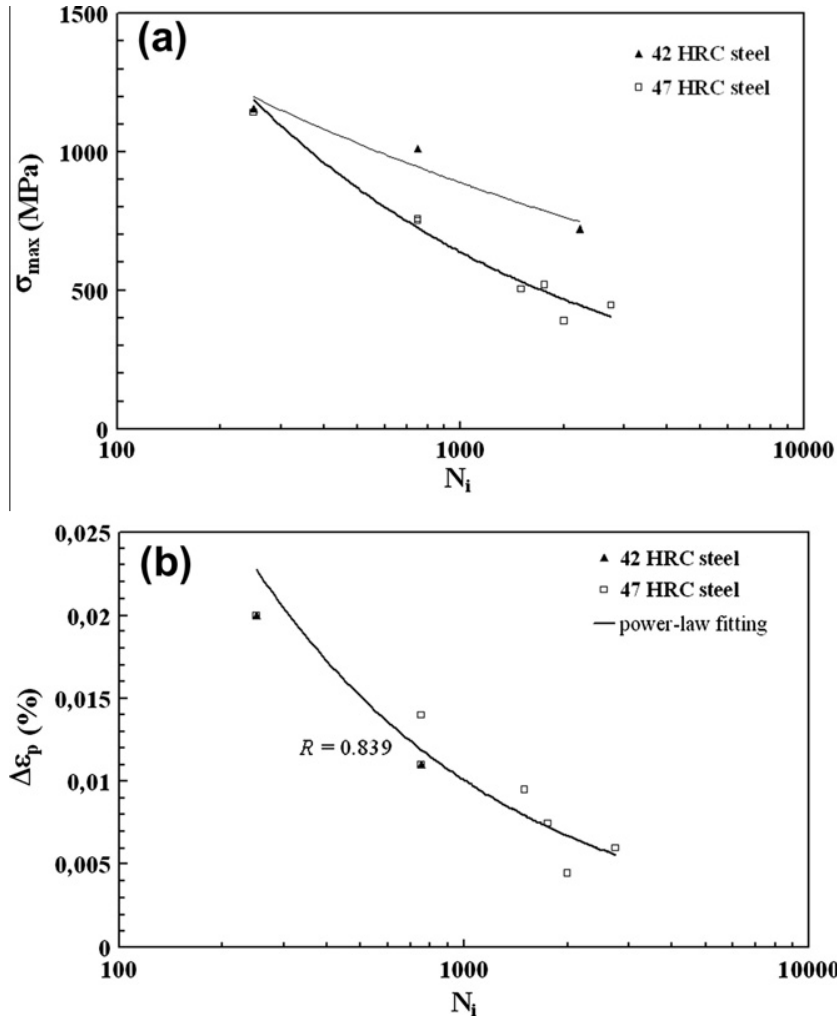

Fig. 18. Effect of maximum stress $\sigma_{\max }$ (a) and plastic strain $\Delta \varepsilon_{p}$ (b) on the number of cycles $N_{i}$ to initiate the microscopic heat-checking.

thermal fatigue loading. Fig. 18a and b respectively show the effects of the maximal stress $\sigma_{\max }$ and plastic strain amplitude $\Delta \varepsilon_{p}$ on the microscopic heat-checking life $N_{i}$. It should be noted that $\sigma_{\max }$ and $\Delta \varepsilon_{p}$ are calculated for the parent steel, since the proper mechanical properties of the oxide layer (which are not really known) could not be included in the FEM analysis [19]. By plotting $N_{i}$ as a function of $\sigma_{\max }$ (Fig. 18a), two different curves were obtained depending on the initial hardness of the steel. This can be attributed to the fact that the maximum stress $\sigma_{\max }$, achieved at $T_{\min }$ of the thermal cycle, is higher for the steel with a lower initial hardness (42 HRC) [19]. This is consistent with thermo-mechanical cycling of many metallic materials, where a higher plastic strain produced at $T_{\max }$ results in higher $\sigma_{\max }$. However, the difference in $\sigma_{\max }$ reduces when the temperature increases. Thus, the hysteresis loops of both steels are quasi identical for $T_{\max }=685^{\circ} \mathrm{C}$ [19], leading to the same micro-crack initiation life $N_{i}$ (as shown in Fig. 18 a).

On the other hand, a single power law is found by plotting $N_{i}$ vs. $\Delta \varepsilon_{p}$ (Fig. 18b):

$\Delta \varepsilon_{p}=0.5813 N_{i}^{-0.587}$.

It can be noted that the exponent found in Eq. (6) is very close to the Manson-Coffin exponent $(c=-0.6)$ generally reported for metallic materials. Therefore, the plastic strain amplitude seems to be a reliable criterion for predicting the micro-cracking initiation in TF experiments, whatever the test conditions and the initial hardness of the base steel.

\section{Conclusions}

Heat-checking of X38CrMoV5 hot work tool steel was investigated under thermal fatigue experiments. The specimen surface was subjected to cyclic induction heating and natural cooling, un- der various test conditions. Thermal cycles, with a minimal temperature of $100^{\circ} \mathrm{C}$ and a maximal temperature $\left(T_{\max }\right)$ ranging from $550^{\circ} \mathrm{C}$ to $685^{\circ} \mathrm{C}$, were performed. The heating time $(h t)$ was also changed for $T_{\max }=650^{\circ} \mathrm{C}$, leading to various maximum heat-flux densities applied on the specimen surface. The tests were regularly stopped and the oxidized surface of the specimen was observed by scanning electron microscopy (SEM). The evolution of the density and morphology of the microscopic crack pattern was quantified using image analysis techniques.

It is shown that the evolution of the heat-checking density vs. number of cycles presents a sigmoidal trend and achieves rapidly a saturated density regime following the crack pattern initiation. It was observed that the heat-checking density is independent of the maximum temperature of the thermal cycle, whereas an increased heating rate leads to a higher micro-cracks density. The size of the heat-checking cells observed in the saturated regime can be linearly related to the maximum heat-flux density applied during the heating period. It is shown that the energy transmitted to the specimen leads to the cracking of the oxide layer, until a certain limit corresponding to the smallest size of the heat-checking cells. The difference between the thermo-mechanical strains in the oxide layer and in the parent steel can explain the change in crack density observed on the surface of the TF specimen. The initial hardness of the steel has no effect on the heat-checking density and morphology.

Whatever the parameters of the thermal cycle (i.e. low or high maximum temperatures, slow or fast heating rates), the crack patterns exhibit a strong similarity in the stabilized regime. Two preferential orientations are observed for the micro-cracks, corresponding to the longitudinal and circumferential axis. Although the size of the heat-checking cells may vary, their shape and orientation remain almost unchanged. All the saturated heatchecking networks are nearly trivalent and isotropic.

The initiation of the microscopic heat-checking is strongly delayed when the temperature amplitude of the thermal cycle decreases, and in a lesser extent when the heating time increases. It is shown that the number of cycles to crack initiation is less dependent on the oxide scale thickness than on thermo-mechanical loading imposed to the specimen. It appears that a criterion based on plastic strain amplitude rationalizes the TF heat-checking life, independently of the initial hardness of the steel.

\section{Acknowledgments}

The authors would like to thank the CTIF (French Technical Centre of Foundry), and especially Dr. Hairy, for supporting a part of this activity. The French National Program on Forging (ACRII and Simulforge) and CETIM are also acknowledged for financial support.

\section{References}

[1] Da Silva CRS, Boccalini M. Thermal cracking of multicomponent white cast iron. Mater Sci Technol 2005;21:565-73.

[2] Dai WS, Ma M, Chen JH. The thermal fatigue behavior and cracking characteristics of hot-rolling material. Mater Sci Eng A 2007;448:25-32.

[3] Persson A, Hogmark S, Bergström J. Thermal fatigue cracking of surface engineered hot work tool steels. Surf Coat Technol 2005;191:216-27.

[4] Srivastava A, Joshi V, Shivpuri R. Computer modeling and prediction of thermal fatigue cracking in die-casting tooling. Wear 2004;256:38-43.

[5] Jean S, Miquel B, Le Roux S, Rézaï-Aria F. An investigation on heat checking of hot work tool steels. In: Proceedings of the 5th international tooling conference. Tool steels of the next century. Leoben (Austria): Institut für Metallkunde und Werkstoffprüfung: 1999. p. 185-9.

[6] Medjedoub F, Dour G, Rézaï-Aria F, Hairy P. Damage to die casting dies through crazing by thermal fatigue: origins mechanisms and approaches. Fonderie Fondeur d'Aujourd'hui 2005;244:22-37.

[7] Fazarinc M, Muhič T, Kugler G, Terčelj M. Thermal fatigue properties of differently constructed functionally graded materials aimed for refurbishing of pressure-die-casting dies. Eng Fail Anal 2012;25:238-49. 
[8] Klobčar D, Tušek J. Thermal stresses in aluminum alloy die casting dies. Comput Mater Sci 2008;43:1147-54.

[9] Engler-Pinto Jr. CC, Su X, Lasecki JV, Chen X, Allison JE. Thermo-mechanical fatigue analysis of cast aluminum cylinder heads. In: Proceedings of materials science \& technology conference, Detroit (USA); 2007, p. 1546-57.

[10] Mazur Z, Luna-Ramírez A, Juárez-Islas JA, Campos-Amezcua A. Failure analysis of a gas turbine blade made of Inconel 738LC alloy. Eng Fail Anal 2005;12:474-86.

[11] Kamaya M, Taheri S. A study on the evolution of crack networks under thermal fatigue loading. Nucl Eng Des 2008;238:2147-54.

[12] Fissolo A, Amiable S, Ancelet O, Mermaz F, Stelmaszyk JM, Constantinescu A, et al. Crack initiation under thermal fatigue: an overview of CEA experience. Part I: Thermal fatigue appears to be more damaging than uniaxial isothermal fatigue. Int J Fatigue 2009;31:587-600.

[13] Salem M, Lamesle P, Dour G, Le Roux S, Rézaï-Aria F. Interaction between aluminizing, oxidation and thermal fatigue in aluminium die casting tool. In: Gutenberghaus, editor, Proceedings of the 9th international tooling conference (Tool 2012), Leoben (Austria); 2012, p. 357-64

[14] Rézaï-Aria F, Oudin A, Jean S, Miquel B, Lamesle P. An investigation on thermal and thermomechanical fatigue of X38CrMoV5 (AISI H11) tool steel. In: Proceedings of 21th international die casting congress \& exposition (NADCA), Cincinnati, Ohio (USA); 2001, p. 353-60.

[15] Meyer-Olbersleben F, Engler-Pinto Jr CC, Rézaï-Aria F. On thermal fatigue of nickel-based superalloys. ASTM STP 1996;1263:41-55.

[16] Bernstein HL, Grant TS, Mc Clung RC, Allen JM. Prediction of thermalmechanical fatigue life for gas turbine blades in electric power generation. ASTM STP 1993;1186:212-38.
[17] Dour G, Medjedoub F, Le Roux S, Diaconu G, Rézaï-Aria F. Normalized thermal stresses analysis to design a thermal fatigue experiment. J Therm Stress 2005;28:1-16.

[18] Le Roux S, Medjedoub F, Dour G, Rézaï-Aria F. Image analysis of microscopic crack patterns applied to thermal fatigue heat-checking of high temperature tool steels. Micron 2013;44:347-58.

[19] Medjedoub F. Détermination des paramètres influant sur le phénomène d'endommagement par fatigue thermique des moules en fonderie sous pression d'aluminium. PhD Thesis. Ecole des Mines de Paris; 2004.

[20] Evans HE, Lobb RC. Conditions for the initiation of oxide-scale cracking and spallation. Corros Sci 1984;24:209-22.

[21] Korneta W, Mendiratta SK, Monteiro J. Topological and geometrical properties of crack patterns produced by the thermal shock in ceramics. Phys Rev E 1998;57:3142-52.

[22] Schütze M. Protective oxide scales and their breakdown. New York: John Wiley \& Sons; 1997.

[23] Zhu XF, Zhang B, Gao J, Zhang GP. Evaluation of the crack-initiation strain of a Cu-Ni multilayer on a flexible substrate. Scripta Mater 2009;60:178-81.

[24] Zhao MH, Fu R, Lu D, Zhang TY. Critical thickness for cracking of $\mathrm{Pb}\left(\mathrm{Zr}_{0.53} \mathrm{Ti}_{0.47}\right) \mathrm{O}_{3}$ thin films deposited on $\mathrm{Pt} / \mathrm{Ti} / \mathrm{Si}(100)$ substrates. Acta Mater 2002;50:4241-54

[25] Jansson NE, Leterrier Y, Månson JAE. Modeling of multiple cracking and decohesion of a thin film on a polymer substrate. Eng Fract Mech 2006;73:2614-26. 